\title{
A Kind of Newspaper Genre in English Newspapers of Pakistan
}

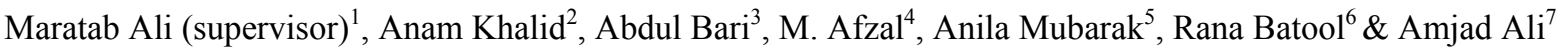 \\ ${ }^{1}$ Department of Linguistics, University of Lahore, Pakistan. E-mail: maratab_abid@yahoo.com \\ ${ }^{2}$ Department of Linguistics, University of Lahore, Pakistan. E-mail: anam.mphil@hotmail.com \\ ${ }^{3}$ Department of Linguistics, University of Lahore, Pakistan. E-mail: barikhan43@yahoo.com \\ ${ }^{4}$ Department of Linguistics, University of Lahore, Pakistan. E-mail: afzallak.aec@gmail.com \\ ${ }^{5}$ Department of Linguistics, University of Lahore, Pakistan. E-mail: zarabanishan@yahoo.com \\ ${ }^{6}$ Department of Linguistics, University of Lahore, Pakistan. E-mail: Subhearooj@yahoo.com \\ ${ }^{7}$ Department of Linguistics, University of Lahore, Pakistan. E-mail: amjadali38403@gmail.com \\ Correspondence: Anam Khalid, Department of Linguistics, University of Lahore, Pakistan. E-mail: \\ anam.mphil@hotmail.com
}

Received: February 15, 2015 Accepted: May 17, 2015 Online Published: May 30, 2015

doi:10.5539/ijel.v5n3p106 URL: http://dx.doi.org/10.5539/ijel.v5n3p106

\begin{abstract}
Transitivity analysis helps to figure out the participants and processes involved in a sentence or in a clause. It can be applied to find out how the writers have presented the public thoughts in letters written to editors by public and how the writers made it attractive by pseudo-descriptive techniques. Our aim of this paper is to carry out transitivity analysis of letters written to editors and by doing so, proving that letters written to editors belong to a separate genre, they are not part of news paper. The language, style of these letters show that they belong to a separate genre, newspaper genre. Our significance of this research paper is to highlight how the different writers use different strategies and vocabulary and add color while showing the letters written by public in order to make their news paper attractive, eye wedged, valuable, and favorable for their readers and also they use strategies and agencies to hide their motives and biasness. The writers also hide their ideologies behind the words in such a way that the readers cannot get access to it so easily. Our focus in this research is to figure out those tactics which the writers adopt to make themselves at value position and how the writers manipulate the minds of eventual readers and provide them an explicit track due to which readers are convinced to think about the issue. Keeping in mind the CDA and SFL theory, we have used SFL to analyze how letters written to editors belong to a separate genre which is the particular aim of this study. The data has been collected from The News, The Dawn, and Daily News on the issue of peace process talks between government of Pakistan and Taliban.
\end{abstract}

Keywords: systematic functional grammar, CDA, Dawn news, The Nation news, Daily news, transitivity analysis

\section{Introduction}

\subsection{Systemic Functional Linguistics and Its Relation to CDA}

Systemic-Functional Linguistics (SFL) is an approach which was proposed by M.A.K and his co workers. Fundamentally it was based on the previous work of various linguists. Dominant among those were J.R. Firth and Bronislaw Malinowski. Malinowski carried out much of his at England and was an anthropologist. In recent decade, SFL approach is being used predominantly in studying language education, and its usage is also beneficial for various purposes of discourse analysis. Most of the linguistic theories deem language as an intellectual process where as SFL is allied in the midst of Sociology. SFL approach figures out usage of language in shared contexts in order to conquer convinced goals. Purpose of SFL is not to covenant with comprehension and fabrications of individual intellect, somewhat it aims at the discourses we sheer whether written or orally spooked and the backgrounds of these utterances. The core aim of SFL is to deal with function of language that why language is used rather than focusing on structure of language structure. A number of events in which SFL is identified are: 
1. Grammar is controlled not only in stipulations of module of units, but is controlled in terms of functions it performs (Subject, Actor, etc.).

2. In SFL, every single utterance is identified through the function it performs in utterance, e.g., bountiful information, challenging information, serious action or contribution action

3. It views texts on the whole in order to convey information, and establish social relations.

4. Language is not an apparatus for proclamation, to a certain extent it is communication itself. Language conveys thoughts, judgment and lexis.

For Halliday, language is a "social act" which intermingles with the scrutiny of CDA supporters. By investigation of structure, van Dijk revenue analyzing "structures at diverse classification of depiction" which is done not only at grammatical, phonological, lexical and Semantic level, rather it is based on elevated level properties like lucidity, overall themes and topics of news stories and the entire graphic forms and proportions of text.

\subsection{Genre Theory}

Jim Martin was the first who proposed genre theory in 1980, along with him was Joan Rothery from Sydney. Genre theorists didn't aim at developing a new genre; rather they acknowledged them by in-depth scrutiny of various texts. They popped out from analyzing evaluation and lettering tasks. Genre theory is linked to systemic functional linguistic (SFL) theory of Halliday and it is a theory about language, framework and text. Genre theory justifies that while selecting the language of any text grammatical choices are put in consideration to craft texts. There is a strong relationship that lies between text and framework. It is the framework, the background which adds colors to text. A genre is a text type. Systemic Functional approaches play vital role in comprehension of how a genre can be understood and applied in textual analysis.SFL involves social perspective, and looks at how language is constrained and acted upon in social context.

\subsection{Four Main Claims}

Various linguists tried their level best to explore how language is used by people in their daily life. These concentrations escort SFL linguists to press forward four main speculative assertions towards language:

Language is used according to its function. Function of language is to create meaning

Meanings of language in which they are exchanged are predisposed by the collective and intellectual framework Language is a process in which speaker produces meaning of utterance on basis of choosing.

SFL focuses on choices adopted by speakers in language usage. These choices lay down the path for exploring the choices used by editors or writers and figure out the supremacy associations and give us the clue why editors have adopted these choices. Language has infinite combinations as a system of choice. Constructing the notion of existential paradigms proposed by David Brazil, Michael McCarthy writes "In bona fide contexts, the assortment of an entry could occur only from diminutive series of conceivable choices or undeniably do not correspond to a factual preference at all" (McCarthy, 1998, p. 70).

\subsection{Conducting CDA through SFL}

Critical Discourse Analysis (CDA) is an approach which intentionally concentrates on supremacy, dogma and control all the way through detailed and in depth investigation of text and framework that sees language as insight of dogma and also as an in ignorant part of social life (Fairclough, 2003). Scrutiny of language in CDA concentrates on examination of dogma of explicit texts figured out in the course of suppositions. Aspire of CDA is to covenant societal and biased consequence and supremacy issues.

\subsection{Systemic Functional Linguistics and Its Role in CDA}

According to SFL we perform different functions through language. So we have a purpose of doing or saying something in our mind when we utter words. SFL sets out to investigate what the range of relevant choices is in meanings that we want to express and in wording in which we express these meanings.

Both CDA and SFL approach are systematically orientated towards studying the relationship between the texture of texts and their social contexts. Within SFL, three kinds of meaning (or functions) have been identified: (Thompson, 1996)

1) Language is used to converse regarding familiarity of world, together with the worlds built on our own (experiential meaning). 
2) Language is used for interaction with various people, to ascertain and sustain associations among them (interpersonal meaning).

3) Language is used to categorize our communication in customs that signify how they fit in with the other messages around them and with the wider context in which we are talking or writing (textual meaning).

Experiential aspect of meaning is analyzed through the system of transitivity. The system of transitivity consists of different process types, participants and circumstances. In English there are six process types: material process, behavior process, mental process, verbal process, relational process, and existential process. Material process is the process of doing things; Behavioral process is the process of psychological behavior such as breathing, crying, drinking... Mental process is a kind of activity in people's mind, such as thinking, loving, wanting, hearing. Verbal process is the process of saying such as saying, telling, speaking, and talking. Relational process is the process of 'being', 'having' and 'being at' in form of three subtypes: the intensive, the possessive, and the circumstantial. Existential process is the process of existing, indicating that something or some natural force exists. Table 1 is an overview of these processes.

Table 1. Overview of process types (adapted from Halliday, 1994)

\begin{tabular}{llll}
\hline Process types & $\begin{array}{l}\text { Category } \\
\text { meanings }\end{array}$ & Participants & Example \\
\hline Material : & 'doing' & Actor, Goal, Recipient & $\begin{array}{l}\text { The girl closed the door } \\
\text { The principal renewed the contract }\end{array}$ \\
Action & 'doing' & & \\
Event & 'happening' & & She cried abruptly. \\
Behavioral : & 'behaving' & Behavior, (Phenomenon) & I heard a noise outside. \\
Mental: & 'feeling' & Sensor, Phenomenon & The boy loved the girl. \\
Perception & 'sensing' & & You can imagine his reaction. \\
Affection & 'emotive' & & \\
Cognition & 'thinking' & & I explained to her what it meant. \\
Verbal: & 'saying' & Sayer, Target, Verbiage, Recipient & This bread is stale. \\
Relational: & 'being' & Carrirer, Attribute & Pat is her brother. \\
Attribution & 'attributing' & Identified, Identifier/ Value, Token & \\
Identification & 'identifying' & & Maybe there's some other darker pattern. \\
Existential: & 'existing' & Existent &
\end{tabular}

\section{Literature Review}

Malinowski main concern was to highlight understanding of "context of situation". As he says:

Our task is rather to show that even the sentence is not a self-contained, Self-sufficient unit of speech. Exactly as a single word is save in exceptional Circumstances meaningless, and receives its significance only through the Context of other words, so a sentence usually appears in the context of other Sentences and has meaning only as a part of a larger significant whole. I think that it is very profitable in linguistics to widen the concept of context so that it embraces not only spoken words but facial expression, gesture bodily activities, the whole group of people present during an exchange of 6 utterances and the part of the environment on which these people are engaged. (Malinowski, 1935, p. 22)

He says the meanings of lexis exist in background to cite the position where they are used:

In any narrative, lexis is used along with a rented or circuitous meaning. The bona fide framework of allusion should be rebuilt with the hearers yet to be evoked by the speaker. The conditions in which the equivalent lexis are used in the company of all practical vitality of a demand or vital, with all the expressive substance of expectation or despondency and conditions in which that lexis usage is laden with substantial penalty for speaker and hearers, in such conditions we communicate in a crucial, straight mode. From such situations the meanings of words are understood relatively than from learning of consequential uses of speech. (Malinowski, 1935, p. 46)

SL [systemic linguistics] is an avowedly functionalist approach to language, and it is arguably the functionalist approach which has been most highly developed. In contrast to most other approaches, SL explicitly attempts to combine purely structural information with overtly social factors in a single integrated description. Like other functionalist frameworks, SL is deeply concerned with the purposes of language use. Systemicists constantly ask the following questions: What is this writer (or speaker) trying to do? What 
linguistic devices are available to help them do it, and on what basis do they make theirchoices? (Robert Lawrence Trask \& Peter Stockwell, Language and Linguistics: The Key Concepts. Routledge, 2007)

Fairclough noted "All utterances (or what he called texts) are populated, and indeed constituted by snatches of other's utterances, more or less explicit or complete." (Fairclough, 1992, p. 102) In SFL, language is an arrangement of meaning impending (Eggins, 1994; Halliday, 1994). Thomas and Meriel observed that "The most important function of CDA is to shed light on this kind of disguised attitude." (Bloor \& Bloor, 2007, p. 43) Eggins (2004, pp. 10-11), functioning surrounded by the scaffold of Systemic Functional Linguistics (SFL), interprets:

.... a higher level of context to which increasing attention is being given within systemic linguistics is the level of ideology...just as no text can be free of context (register or genre), so no text is free of ideology. In other words, to use language at all is to use it to encode particular positions and values.

Fowler and Kress (1979) challenged "ideology is linguistically mediated" (Young \& Harrison, 2004, p. 4). Ruth Wodak stated "an understanding of the basic claims of Halliday's grammar and his approach to linguistic analysis is essential for proper understanding of CDA" (Young \& Harrison, 2004, p. 4).

M.A.K. Halliday, in dissertation Language as a Social Semiotic: Towards a General Sociolinguistic Theory (1975) saw language as a social semiotic that provides speakers and listeners to swap over meanings that are consequential from each category of societal perspective (Halliday, 2007, p. 171). Halliday considered background as central element for the study and understanding of language.

Young and Harrison (2004, p. 1) spoted three chief areas where SFL and CDA unite: First, SFL and CDA contribute to the scrutiny of language as a shared build which looks at the role played by language in society and at the customs in which society has twisted or shaped language. The second team spirit is their mutual collective dialectical scrutiny of verbal communication in which meticulous discursive proceedings manipulate the backgrounds in which they transpire and the contexts are, in turn, predisposed by these events. Third, both SFL and CDA accentuate the edifying and chronological aspects of meaning. Young and Harrison contend "There is then, a solid tradition that links SFL and CDA from the very advent of Critical Linguistics (CL), the precursor to CDA." SFL "provides a solid methodology that can...help to preserve CDA from ideological bias." Young and Harrison also noted that "one of the strengths of SFL for CDA is to ground concerns with power and ideology in detailed analysis of text in real contexts of language use, thereby making it possible for the analyst to be explicit, transparent, and precise"

Critical Discourse Analysis (CDA) is a multidisciplinary approach of textual scrutiny which is engrossed in finding the function and position of language in explaining societal associations alongside unbalanced ranks. CDA figures out how problems of customs and traditions, creed, discrimination, and group supremacy are articulated, enacted, legitimated and reproduced in text and converse (van Dijk, 1995, p. 19)

"CDA" is widely used to denote a recognizable approach to language study manifested across a range of different groups. Indeed, critical discourse analysis is close to becoming "an intellectual orthodoxy" (Billig, 2002, p. 44), According to Fowler et al. (1979), "the relation between form and content is not arbitrary or conventional, but ... form signifies content" (p. 188). In nutshell, language is a collective performance which takes place intellectualy.

\section{Data Analysis}

\subsection{Application of Transitivity Analysis Dawn Letter 1}

NAWAZ Sharif (Carrier) is not known for having (relational process) a good memory (Attribute) or learning from his mistakes. Does he (Sensor) remember (process) what he said to persuade the defenseless people to re-elect him? (Phenomenon) (Mental Process) He may not. So let me refresh (Goal) his memory (Material Process)

He (Sayer) said, “Andhere Mitta denge" (Verbiage) (We will get rid of the darkness). (Verbal Process)

What darkness (goal) has (process) he (actor) removed? (Material Process) Everywhere, everyone's (carrier) life is (relational Process) threatened (attribute). He calls (action) this 'achievement (circumstance) (existential process)?' We (goal) elected (Material Process) him to lead (goal) is this leadership?

He has shackled the armed forces and is negotiating (relational process) a fake (attribute) peace (carrier) with the Taliban. He (sayer) says 'no talks before ceasefire (verbiage) (verbal process).' Who (actor) told (process) him (goal)? (Material process) On what intelligence has he based his estimate that there will (process) be a ceasefire (circumstance)? (Existential Process). 
He (actor) should know that the Taliban are not interested (process) in peace (goal) (Material process) They (sensor) want surrender (phenomenon)(Mental process). Surrender (process) not of some areas (actor) in Pakistan but the whole of Pakistan (goal) (Material process). Soon, he (actor) will be out (process) on his way to Edgeware (goal) as will the other politicians (Material process). We (actor) will be left (process) to deal with the Taliban (goal): either to surrender or to fight. (Material process)

Get this clear (verbiage), Mr Prime Minister (sayer) (Verbal Process) You are no longer relevant. Do not blame (attribute) the people of Pakistan (carrier) for your fate. (Relational process) You (sensor) chose this path (phenomenon). (Mental process)

God be with you and your family on Edgeware Road, and let God (actor) protect us (goal) from this looming disaster (action) (Material Process).

\subsection{Application of Transitivity Analysis Dawn letter 2}

THERE has been (process) a state of 'phoney war' (actor) between the state of Pakistan and the various terrorist (goal) organisations since 2001 (Material Process) We (actor) took (Process) some right steps in Swat years later, but once again we are on the verge of appeasing (goal) these neo-fascist pseudo-Islamist factions. (Material Process)

All this melodrama reminds (sensor) me of the appeasement policy of Neville Chamberlain during a few years prior to the outbreak of World War II (phenomenon) (Mental Process). We (actor) are (Process) bleeding (Material Process), we (carrier) are being (process) bombed off (attribute) to hell (Relational Process) and all our Chamberlains (actor) seem to be concerned about (Process) is how to appease (goal) the Taliban (Material Process) and somehow, with some sort of sorcery (actor) perhaps, stop them (process) from all this frenzy (goal) (Material Process).

It will be for the first time in the history of modern states perhaps that a nuclear power (actor) has (Process) bowed down and given in to bullying terrorist bands (goal) (Material Process)

Imran Khan (actor) and some other politicians are (Process) working hard to achieve 'peace for our time' (goal) like Chamberlain did once but it seems we (actor) have no Winston Churchill who could tell them that Pakistan had been offered a choice. (Material Process) "between war and shame (goal). It (actor) has chosen (process) shame, and will get war (goal)." (Material Process)

Didn't this (actor) happen (process) in Swat (goal) already? (Material process) We (actor) gave (process) the TTP and TNSM what they wanted (goal) (Material Process). And did it (actor) stop (Material Process) them (goal)? What is different with Waziristan? We (actor) are (Process) again trying (process) to choose dishonor just to avoid war (goal) and in the end we will be dishonored and get a war (Material Process)

We (actor) need (process) a Churchill (goal) (material Process). We (actor) need (process) someone to tell us (goal) 'Gentlemen, (material Process) We (existent) are at war because it is the only road leading to lasting peace (circumstance) (Existential process)' Are we (existent) going to live in this nightmare forever? (circumstance) (Existential process) Are we (existent) going to face this humiliation forever? (circumstance) (Existential process) Are we (existent) going to give in to those uneducated fanatics from Saudi Arabia, Afghanistan, Chechnya, Tajikistan, Uzbekistan and what not? (circumstance)(Existential process) Are we (actor) going to let them destroy us (goal) because 'they have some of our own people fighting among their ranks?' (material Process) A tree (actor) cannot be cut down (process) until an axe (goal) is provided with a wooden handle. Solution? (material process). Destroy the axe (sensor) with the handle if you want to save your tree (circumstance). (Mental Process)

\subsection{Application of Transitivity Analysis Dawn Letter 3}

Our civilian government (Actor) has finally decided to throw away (Process) the carrot (goal) and use (Process) the stick (actor) to control the TTP (goal) and also gave us an idea (process) how they (actor) plan to proceed (goal)(material process). It (actor) also seems to have selected (Process) the model for the elimination of the Liberation Tigers of Tamil Eelam (LTTE) by the Sri Lankan military. (Goal)

The TTP (actor) is no match for the LTTE which between 1976 and 2009assassinated (Process) one Sri Lankan president and an Indian prime minister. (goal) During this dark period of Sri Lankan history (sayer) there was no Bush (fire) like Sept 11 (vebriage). The LTTE (actor) was not founded (process) on the outskirts of 9/11 but was founded in May 1976 (goal). The LTTE (actor) was a secessionist movement fighting (process) for an independent state in the north and east of Sri Lanka for the Tamil-speaking people (goal). The TTP (Beneficiary) is the byproduct of the Afghan Taliban (goal) and also has (process) a large number of leftovers of Al Qaeda (actor). The Sri Lankan (actor) army never required the advice (process) of APC-style (goal) time-wasting antics. 
Instead, they(actor) themselves pioneered (process) the peace process with the LTTE (goal) and having failed (process) to achieve the results through dialogues (actor) launched a major offensive (goal) in 2006 (similar to our Swat operation) and defeated (process) the LTTE (actor) in 2009 (goal).

It (actor) took less than three years to achieve (process) the results (goal). Our political parties (carrier) have (relational process) divergent views (attribute) on the status of the TTP as an anti-state (attribute) militant group. Our two bordering nations also have (relational process) soft corners (attribute) for the TTP (carrier).In such circumstances the Pakistan Army (actor) must immediately take initiative (material process) like the Swat operation and launch a major offensive (goal) from Karachi to Khyber.

Mohammad Iqbal

Karachi

\subsection{Application of Transitivity Analysis The Nation 1}

Maulana Aziz is on the payroll of Capital Development Authority (CDA), a statutory government (actor) organization has issued (material process) a statement which primarily expresses his personal doubts about the ongoing peace (goal) talks not succeeding within ambit of constitution.

He (actor) has been (Process) casting aspersions about the Taliban(goal) not being willing to accept the Constitution. (Material Process)

The manner in which private television channels (actor) has been (Process) giving (material process) exposure to Maulana Aziz (goal), who neither has a mandate nor a conscience to behave in the manner expected from a government paid servant (actor) seems to be (material process) part of a tendency of the media to indulge in sensationalism (goal), irrespective of the damage it may impose (sensor)to our national interests for ratings(phenomenon) (Mental Process)

This gentlemen (carrier) nominated (attribute) by TTP is on record of having (Relational Process) supported their struggle. He has never expressed (sensor) his disagreement on armed struggle launched by TTP, including practice of sending young men on suicide missions, who have been brainwashed to believe that embracing Shahadat, entitles them an assured place in heaven (phenomenon). (Mental Process)

The glaring contradiction between what he (sensor) preaches and his acts was highlighted earlier (phenomenon) (Mental Process), when he (actor), instead of embracing the much preached 'Shahadat (goal)' in LalMasjed tragedy, preferred to sneak out (Process) wearing a Burka, (Material Process)(a female covering) while younger boys and girls(sensor)who had never even seen anything of the real world or enjoyed their youth were made to stay put and suffer (Process) a brutal death (phenomenon). (Mental Process)

If Maulana (actor) does not believe in supremacy of the Constitution (goal), which includes clauses that no laws will be framed (process) against Quran and Sunna, why does he receive a salary from CDA? (Material Process)

The Constitution of Pakistan is the basic law on which the foundation of a democratic state can thrive (circumstance) and exist (existent) (Existential Process)

If Constitution (actor) is held in abeyance, or abrogated, than instead of 'Rule of Law' (goal), it will be (process) 'Rule of Men' or individuals. (Material Process)

No individual or group bearing arms, be they (actor) under the garb of religious extremists, sectarian cults or political mafia involved in illegitimate acts, should be allowed to be seen trampling the constitution (process), defy writ of state, make a mockery of judicial system (goal), nor impose their beliefs and interpretation of Shariah on the vast majority of citizens of this Muslim nation. (Material Process)

\subsection{Application of Transitivity Analysis The Nation 2}

The Nationcarried MrSaadRasool's (Carrier) thought provoking article, "Khan's apologists” (Relational Process)

Anybody (sensor) not part of the TTP but on the negotiation table has to be credible, neutral, sincere and commanding more than good influence on the TTP leadership (phenomenon). (Mental Process)

It (actor) is no simple matter to arrive (process) at easy solutions and assurances of possible end result (goal). (Material Process)

We (sensor) are facing a very complex issue (phenomenon). (Mental Process)

The government's committee (actor) in its initial meeting with TTP negotiators presented (process) five points of which the most important was "the talks should be held within the framework of the constitution of the Islamic Republic of Pakistan"(goal). (Material Process) 
The other important conditions were that the authority of TTP negotiators (behaver) (and its monitoring committee) be made clear: and dialogue process should be quick and speedy (Behavioral Process)

Anything outside the framework of the constitution (existent) will be illegal. (existential process)

The proper forum for consideration of any (phenomenon) logical and reasonable demands of the TTP (sensor) is the parliament. (Mental Process)

The parliament (actor) should be ready to consider the demands if violence is stopped (process) and the focus remains on troubled areas (goal) only. (Material Process)

As the Prime Minister Nawaz Sharif (Sayer) has recently said, "rectifying wrong policies is a must to defeat terror" (Verbiage)(Verbal Process).

In this context all political parties (actor) represented in the parliament have (process) the responsibility to work together and work hard for this national cause (goal).(Material Process)

Street politics and violence (existent) is not what we need. (Existential process)

Good citizenship means that we (sensor) love our country and accept the writ of the state(phenomenon). (Mental Process)

It (actor) is important to distinguish (process) the state from the government (goal) (Material Process). Army's announcement of ceasefire should not be taken as weakness (attribute) of the government (carrier). (Relational Process)

This is an opportunity for TTP to lay down arms and all criminals should be treated according to the law. (Behavioral Process)

Though it looks (sensor) as if the desired peace is near, the majority of the conditions are a challenge to the writ of the state, which means that peace would remain a distant dream as those conditions of the TTP are against the interest of the state of Pakistan and its people (phenomenon)(Mental Process) Terrorists (actor) who belong to other countries must be handed over (process) to Pakistani authorities for legal action (goal) against them. (Material Process)

\subsection{Application of Transitivity Analysis The Nation 3}

Today in two different terrorist incidents in Peshawar and Karachi several persons (actor) were killed (material process), and injured (goal). The first blast (circumstance) took place ((existential process) outside Park Hotel in KuchaRisaldar. (existent) The second blast (actor) uprooted the rail tracks derailing (material process) Shalimar Express (goal). Several passengers (actor) sustained (material process) injuries (goal). It has not been (relational process) determined which terrorist (carrier) outfit was involved in these dastardly attacks (attribute). These atrocities (carrier) are being (relational process) committed (attribute) while negotiations process has been initiated. The occurrence (material process) of these incidents negates the good intentions expressed by the TTP (actor) for the peace process (goal). These can prove to be (relational process) the stumbling (attribute) block (carrier). The terrorist (actor) groups or some third party wants to (material process) sabotage the negotiations (goal). We (actor) cannot rule out (material process) India's involvement in these activities (goal). A political drama (carrier) is being (relational process) staged and enacted (attribute) in broad day light. Media (actor) must act responsibly and avoid spreading (material process) unconfirmed information (goal).

No one has claimed (material process) responsibility for the attacks and I (actor) suspect no one would claim (goal) it either! KPK government (actor) needs to (material process) beef up the security (goal) so that such incidents do not occurred.

TTP (actor) has disclaimed (material process) the Peshawar bomb blast (goal) and If that is true then we (actor) need (material process) to see who is responsible for the incident (goal)? All terrorist groups (carrier) remain in contact with each other, and have (relational process) inside information (attribute). It is (relational process) incumbaent on the State (carrier) to protect its citizens, and respond to such nefarious (attribute) activities. A number of religious scholars (carrier) have been (relational process) brutally (attribute) killed in suicide attacks. QadirBaloch (actor) warned (material process) that the government (goal) would have to retaliate if these attacks continue. He further said (verbiage, verbal process), that, he does not want to indulge in blame game and would like to see the peace talks proceed in a cordial atmosphere. (saying)

JAVAID BASHIR, Lahore, February 4. 


\subsection{Application of Transitivity Analysis The News 1}

Regardless of what happens to the ongoing negotiations, the problem (goal) we (actor) are facing (process) is not going to go away (material Process). This (actor) is (material process) the battle (goal) for the soul of Pakistan. On one side are the weapons (carrier)-wielding obscurantists (attribute) (relational Process), while on the other are those who wish (sensor) to see Pakistan develop as a tolerant state based on equality, democracy and human freedom (phenomenon)(Mental Process). A huge chunk of the population (sensor), disgusted with the corrupt administrative system and abject poverty, seem to fantasize about an Islamic state (phenomenon)(Mental Process). Women (sensor), the silent sufferers, have no say, as they are either too suppressed by traditions or awed by the thought of rebelling against their only security of home in a cruel society and state (phenomenon)(Mental Process). This struggle (actot) will not (goal) end till the soul of Pakistan (goal) is won over by either side (Material Process). Deferring (actor) the inevitable will not (process) solve the problem (goal). (Material Process) We (sensor) will neither progress nor live in peace without deciding this issue once and forever (phenomenon). (Mental Process)

\subsection{Application of Transitivity Analysis The News 2}

If, as per reports, the Taliban (actor) claim they have not (process) carried out violent activities (goal) in the past few days then who is responsible for them? (Material Process) It (actor) also raises (process) serious questions (goal) over the dialogue process. (Material Process) If terrorist (actor) activities will not end by holding dialogue (goal) with the TTP, then why have the talks? (Material Process) What has been (process) the government's (actor) role in identifying the real groups (goal) behind the attacks? (Material Process) Does it mean that in the future, even if dialogues (actor) are successful (process), terrorist activities (goal) will continue? (Material Process) The government (sensor) needs to put this question to the Taliban and itself and needs to avoid the policy of appeasing the TTP (phenomenon) (Mental Process). In any case, an end to terrorist (actor) activities is the successful outcome (goal) of dialogues (process) with the TTP (Material Process). Anything less than this is failure and should not be accepted by the government (behaver) (Behavioral Process)

\subsection{Application of Transitivity Analysis The News 3}

There are many confusion-mongering people (sensor) in the media, the intelligentsia and the political and religious parties who have been instrumental in confusing and complicating the issue of terrorism (phenomenon) (Mental Process). Their (sensor) false narratives, flawed logic and unrealistic suggestions have virtually put the nation in a blind alley (phenomenon)(Mental Process). The Pakistan Army (actor) has successfully concluded (process) military operations against miscreants(goal) in Swat, South Waziristan and Bajaur (Material Process) But the confusion brigade (sensor) is portraying the dialogue process as the only remedy that will get the country out of this mess (phenomenon).(Mental Process) Instead of uniting the nation to fight this war, the confusion bridge (sensor) is busy demoralising people by exaggerating the 'might' of the miscreants and the 'consequences' of the failure of this dialogue process (phenomenon) (Mental Process). As a result, we (actor) are debating and discussing (process) issues (goal) such as whether this is Americans' war or ours (Material Process). Who (actor) is (process) a real martyr (goal) in this war? (Material Process) Whether we (actor) need the supremacy of the constitution (process) or the TTP-defined Shariah (goal). (material Process) Now, the TTP spokesman ShahidullahShahid (actor) has recommended (process) the name of Mullah Fazlullah to lead Pakistan (goal) (Material Process). Instead, I (sensor) suggest a person like the schoolboy AitzazHasan should lead this country, someone who not only has the vision to perceive the nature of the threat within seconds but also has the required courage to counter it. (phenomenon)(Mental Process)

Table 2. Analysis of data in tabular form

\begin{tabular}{llllllllll}
\hline News paper & Dawn 1 & Dawn 2 & Dawn 3 & Nation 1 & Nation 2 & Nation 3 & The News 1 & The News 2 & The News 3 \\
\hline Material Process & $\mathbf{9}$ & $\mathbf{1 6}$ & $\mathbf{1 5}$ & $\mathbf{8}$ & $\mathbf{5}$ & $\mathbf{1 2}$ & $\mathbf{4}$ & $\mathbf{6}$ & $\mathbf{5}$ \\
Behavioral Process & $\mathbf{0}$ & $\mathbf{0}$ & $\mathbf{0}$ & $\mathbf{1}$ & $\mathbf{2}$ & $\mathbf{7}$ & $\mathbf{0}$ & $\mathbf{1}$ & $\mathbf{0}$ \\
Mental Process & $\mathbf{3}$ & $\mathbf{2}$ & $\mathbf{0}$ & $\mathbf{0}$ & $\mathbf{2}$ & $\mathbf{0}$ & $\mathbf{4}$ & $\mathbf{1}$ & $\mathbf{5}$ \\
Verbal Process & $\mathbf{2}$ & $\mathbf{1}$ & $\mathbf{1}$ & $\mathbf{4}$ & $\mathbf{5}$ & $\mathbf{0}$ & $\mathbf{0}$ & $\mathbf{0}$ & $\mathbf{0}$ \\
Relational Process & $\mathbf{4}$ & $\mathbf{0}$ & $\mathbf{2}$ & $\mathbf{0}$ & $\mathbf{1}$ & $\mathbf{1}$ & $\mathbf{1}$ & $\mathbf{0}$ & $\mathbf{0}$ \\
Existential Process & $\mathbf{2}$ & $\mathbf{4}$ & $\mathbf{0}$ & $\mathbf{1}$ & $\mathbf{2}$ & $\mathbf{1}$ & $\mathbf{0}$ & $\mathbf{0}$ & $\mathbf{0}$ \\
\hline
\end{tabular}

\section{Conclusion}

Transitivity analysis is extensively used to recognize the language which speakers and writers use and to comprehend the function of that particular language used. Transitivity analyses observes the constitution of 
sentences and checks out which processes are carried out in each sentence, which participants are occupied in these processes, and in what state of affairs the processes and participants are involved. Using transitivity analysis, our aim of this research paper was to reveal that language constitutions fabricate assured meanings and dogma which is not always overt for readers. The objective of functional analysis, predominantly transitivity analysis, is to ascertain the relation existing between lexis and their interpretations which is conscientious for the association of language characteristics in a text. The concept of transitivity is used to shed more light on the usage of language chosen by editors and writers in texts and news papers. Transitivity analysis of these letters supports to the reader's responses in these letters. In these letters the mostly used processes are material, mental and relational processes. It shows that these letters are conveying the inner world of the people. Every newspaper uses a different style to express the news and highlight the issue. The use of synonyms show the manipulation which the writer does in order to make the news effective. In the same way these letters are not written on the same pattern and they depict the ideology of that particular newspaper. Analysis of these letters and the participants involved in these processes show that the people are frustrated and feeling unsafe in the hands of our government. All the peace talks show that the innocent people being the victim of bloodshed need peace and want this melodrama been eradicated. These letters demand justice from the government and government is not sincerely paying heed on these issues. Mostly used processes in DAWN news letters are material processes which show that government is doer of actions as arranging the peace talks and showing its authority and power of government. Language is used according to its function, what is said depends on what is needed to be accomplished. This analysis showed that how government is in power even after not solving the solution of terrorism and shows how this power is accomplished through study of processes. Dawn newsletters show how furious the people are for seeing nothing done by government for public security and peace talks played no vital role in controlling of terrorist attacks. Newspaper the Nation shows that the writer is focusing on TTP rather than blaming Nawaz Shrif and the writer of the Nation has used a calm way to express the views of public rather than being furious and emotional. The News seems to be neutral. This analysis attracts the people's attention towards power of language in construction. The language of these letters shows that these letters belong to a separate genre because these letters depict their own ideology different from that of newspapers. In conclusion, I wish this research contributes to understanding of how linguistic scrutiny of newsletters is done in order to deduce meanings articulated in letters and contribute in depicting that news letters are not the part of news paper, rather they belong to a separate genre.

\section{Dedication}

I dedicate this work which means a lot to me and on which I worked whole heartedly to my beloved parents in particular who are my ideal and who groomed me and nourished me with inexpressible love and to my family in general. I, who was merely a crude stone had been polished and become a gem under their kind guidance. I dedicate this work to my parents who appreciated me on my every step and always remained a supporting pillar throughout my carrier and special gratitude to my father who guided me and supported me in every aspect and who had a great confidence on me that I can do it and complete this task. Today whatever I am is only because of my parents. Also a special thank to Mian Muhammad Atif Choudhary who remained a good companion and supporter for this research.

\section{Acknowledgements}

I am thankful to Allah Almighty, who has bestowed me with the power of knowledge and who has made me capable to achieve this task. I am also thankful to my all teachers in general and to sir Hafiz Ahmed Bilal, Sir Muratib Ali and Sir Abdul Bari khan in particular who guided me on every step selflessly and appreciated my efforts whole heartedly. A special thank to my beloved sister fairy also who encouraged me to carry out this task. She has really been a great helping hand for me all through my education. She has helped me a lot in making my grammar strong which naturally seemed a difficult task to me. But with her dedicated and selfless efforts and her diligent co operation I have become able to sharpen my weak areas. I am deeply indebted to my sister and all those who helped me in any way for completion of this work.

\section{Refrences}

Eggins, S. (1994). An Introduction to Systemic Functional Linguistics. London: Pinter Publisher.

Eggins, S. (2005). An Introduction to Systemic Functional Linguistics (2nd ed.). Continuum.

Fairclough, N. (1989). Language and Power. London: Longman.

Fairclough, N. (1992). Discourse and social change. Cambridge: Polity Press. 
Fairclough, N. L. (1985). Critical and descriptive goals in discourse analysis. Journal of Pragmatlcs, 9, 739-763. http://dx.doi.org/10.1016/0378-2166(85)90002-5

Fairclough, N. L. (1988). Register, power, and sociosemantic change. In Birch \& Toole (Eds.), Functions of style. Frances Pinter.

Fowler, R., Hodge, R., Kress, G., \& Trew, T. (1979). Language and Control. London: Routledge \& Kegan Paul.

Garinel, H. (1967). Studies in ethnomethodology. Englewood Oifis, New Jersey: Prentice Hall.

Halliday \& Matthiesson. (2004). An Introduction to Functional Grammar (3rd ed.). UK: Hodder Education.

Halliday, M. A. K. (1992a). The history of a sentence: an essay in social semiotics. In V. Fortunait (Ed.), La cultura italiana e le leterature straniere moderne. Bologna: Longo Editore.

Halliday, M. A. K. (1992b). The notion of 'context' in language education. In T. Le \& M. McCausland (Eds.), Interaction and development: proceedings of the international conference, Vietnam, 30 March-1 April 1992. University of Tasmania: Language Education.

Halliday, M. A. K. (1994). An Introduction to Functional Grammar (2nd ed.). London: Arnold.

Levinson, S. (1983). Pragmatics. Cambridge University Press

McCarthy, M. (1991). Discourse Analysis for Language Teachers. Cambridge: Cambridge UniversityPress.

Thompson, N. (1996). Supply side socialism: The political economy of New Labour. New Left Review, 216, 3-54.

van Dijk, T. (Ed.). (1985). Handbook of discourse analysis (vol. 4). Academic Press.

Van Dijk, T. A. (1995). Discourse semantics and ideology. Discourse and Society, 6(2), 243-289. http://dx.doi.org/10.1177/0957926595006002006

Widdowson, H. G. (1979). Explorations in applied linguistics. Oxford University Press.

Wodak, R. (1995). Critical linguistics and critical discourse analysis. In J. Verschueren et al. (Eds.), Handbook of Pragmatics: Manual (pp. 204-210). Amsterdam: John Benjamins. http://dx.doi.org/10.1075/hop.m.cri1

\section{Appendix A}

\section{The DAWN Letter 1:}

PM: some questions

Updated Feb 25, 2014 07:21am

NAWAZ Sharif is not known for having a good memory or learning from his mistakes. Does he remember what he said to persuade the defenseless people to re-elect him? He may not. So let me refresh his memory.He said, "Andheraymittadenge," (We will get rid of the darkness). What darkness has he removed? Everywhere, everyone's life is threatened. He calls this 'achievement?' We elected him to lead. Is this leadership? He has shackled the armed forces and is negotiating a fake peace with the Taliban. He says 'no talks before ceasefire.' Who told him? On what intelligence has he based his estimate that there will be a ceasefire? He should know that the Taliban are not interested in peace. They want surrender. Surrender not of some areas in Pakistan but the whole of Pakistan. Soon, he will be out on his way to Edgeware as will the other politicians. We will be left to deal with the Taliban: either to surrender or to fight. Get this clear, Mr Prime Minister. You are no longer relevant. Do not blame the people of Pakistan for your fate. You chose this path. God be with you and your family on Edgeware Road, and let God protect us from this looming disaster.

Iqbal Ismail Karachi

\section{The DAWN Letter 2:}

\section{'Phoney war'}

Updated Feb 25, 2014 07:21am

THERE has been a state of 'phoney war' between the state of Pakistan and the various terrorist organisations since 2001. We took some right steps in Swat years later, but once again we are on the verge of appeasing these neo-fascist pseudo-Islamist factions. All this melodrama reminds me of the appeasement policy of Neville Chamberlain during a few years prior to the outbreak of World War II. We are bleeding, we are being bombed off to hell and all our Chamberlains seem to be concerned about is how to appease the Taliban and somehow, with 
some sort of sorcery perhaps, stop them from all this frenzy. It will be for the first time in the history of modern states perhaps that a nuclear power has bowed down and given in to bullying terrorist bands. Imran Khan and some other politicians are working hard to achieve 'peace for our time' like Chamberlain did once but it seems we have no Winston Churchill who could tell them that Pakistan had been offered a choice "between war and shame. It has chosen shame, and will get war."

Didn't this happen in Swat already? We gave the TTP and TNSM what they wanted. And did it stop them? What is different with Waziristan? We are again trying to choose dishonour just to avoid war and in the end we will be dishonoured and get a war. We need a Churchill. We need someone to tell us 'Gentlemen, We are at war because it is the only road leading to lasting peace.' Are we going to live in this nightmare forever? Are we going to face this humiliation forever? Are we going to give in to those uneducated fanatics from Saudi Arabia, Afghanistan, Chechnya, Tajikistan, Uzbekistan and what not? Are we going to let them destroy us because 'they have some of our own people fighting among their ranks?' A tree cannot be cut down until an axe is provided with a wooden handle. Solution? Destroy the axe with the handle if you want to save your tree.

AfaqHussain Karachi February 14, 2014

\section{Dawn Letter 3: Taliban and LTTE}

\section{Updated Feb 21, 2014 07:54am}

OUR civilian government has finally decided to throw away the carrot and use the stick to control the TTP and also gave us an idea how they plan to proceed. It also seems to have selected the model for the elimination of the Liberation Tigers of Tamil Eelam (LTTE) by the Sri Lankan military.

The TTP is no match for the LTTE which between 1976 and 2009 assassinated one Sri Lankan president and an Indian prime minister. During this dark period of Sri Lankan history there was no Bush (fire) like Sept 11. The LTTE was not founded on the outskirts of 9/11 but was founded in May 1976. The LTTE was a secessionist movement fighting for an independent state in the north and east of Sri Lanka for the Tamil-speaking people. The TTP is the byproduct of the Afghan Taliban and also has a large number of leftovers of Al Qaeda. The Sri Lankan army never required the advice of APC-style time-wasting antics. Instead, they themselves pioneered the peace process with the LTTE and having failed to achieve the results through dialogues launched a major offensive in 2006 (similar to our Swat operation) and defeated the LTTE in 2009.It took less than three years to achieve the results. Our political parties have divergent views on the status of the TTP as an anti-state militant group. Our two bordering nations also have soft corners for the TTP. In such circumstances the Pakistan Army must immediately take initiative like the Swat operation and launch a major offensive from Karachi to Khyber.

\section{Mohammad Iqbal Karachi}

\section{The NATION Letter 1:}

\section{A man of no season!}

Maulana Aziz is on the payroll of Capital Development Authority (CDA), a statutory government organization has issued a statement which primarily expresses his personal doubts about the ongoing peace talks not succeeding within ambit of constitution.

He has been casting aspersions about the Taliban not being willing to accept the Constitution.

The manner in which a private television channels has been giving exposure to Maulana Aziz, who neither has a mandate nor a conscience to behave in the manner expected from a government paid servant seems to be part of a tendency of the media to indulge in sensationalism, irrespective of the damage it may impose to our national interests for ratings.

This gentlemen nominated by TTP is on record of having supported their struggle.

He has never expressed his disagreement on armed struggle launched by TTP, including practice of sending young men on suicide missions, who have been brainwashed to believe that embracing Shahadat, entitles them an assured place in heaven.

The glaring contradiction between what he preaches and his acts was highlighted earlier, when he, instead of embracing the much preached 'Shahadat' in LalMasjed tragedy, preferred to sneak out wearing a Burka, (a female covering) while younger boys and girls who had never even seen anything of the real world or enjoyed their youth were made to stay put and suffer a brutal death.

If Maulana does not believe in supremacy of the Constitution, which includes clauses that no laws will be framed against Quran and Sunna, why does he receive a salary from CDA? 
The Constitution of Pakistan is the basic law on which the foundation of a democratic state can thrive and exist.

If Constitution is held in abeyance, or abrogated, than instead of 'Rule of Law', it will be 'Rule of Men' or individuals.

No individual or group bearing arms, be they under the garb of religious extremists, sectarian cults or political mafia involved in illegitimate acts, should be allowed to be seen trampling the constitution, defy writ of state, make a mockery of judicial system, nor impose their beliefs and interpretation of Shariah on the vast majority of citizens of this Muslim nation.

MALIK TARIQ ALI, Lahore, February 12

\section{The Nation Letter 2:}

February 14, 2014

\section{Could we but hope!}

The Nation carried MrSaadRasool's thought provoking article, "Khan's apologists".

Anybody not part of the TTP but on the negotiation table has to be credible, neutral, sincere and commanding more than good influence on the TTP leadership. It is no simple matter to arrive at easy solutions and assurances of possible end result.

We are facing a very complex issue. The government's committee in its initial meeting with TTP negotiators presented five points of which the most important was "the talks should be held within the framework of the constitution of the Islamic Republic of Pakistan".

The other important conditions were that the authority of TTP negotiators (and its monitoring committee) be made clear: and dialogue process should be quick and speedy. Anything outside the framework of the constitution will be illegal.

The proper forum for consideration of any logical and reasonable demands of the TTP is the parliament. The parliament should be ready to consider the demands if violence is stopped and the focus remains on troubled areas only. As the Prime Minister Nawaz Sharif has recently said, "rectifying wrong policies is a must to defeat terror". In this context all political parties represented in the parliament have the responsibility to work together and work hard for this national cause. Street politics and violence is not what we need. Good citizenship means that we love our country and accept the writ of the state.

It is important to distinguish the state from the government. Army's announcement of ceasefire should not be taken as weakness of the government.

This is an opportunity for TTP to lay down arms and all criminals should be treated according to the law. Though it looks as if the desired peace is near, the majority of the conditions are a challenge to the writ of the state, which means that peace would remain a distant dream as those conditions of the TTP are against the interest of the state of Pakistan and its people. Terrorists who belong to other countries must be handed over to Pakistani authorities for legal action against them.

IFTIKHAR AHMAD, Lahore, February 12.

The Nation Letter 3:

February 08, 2014

\section{We are getting nowhere!}

Today in two different terrorist incidents in Peshawar and Karachi several persons were killed, and injured. The first blast took place outside Park Hotel in Kucha Risaldar. The second blast uprooted the rail tracks derailing Shalimar Express. Several passengers sustained injuries. It has not been determined which terrorist outfit was involved in these dastardly attacks. These atrocities are being committed while negotiations process has been initiated. The occurrence of these incidents negates the good intentions expressed by the TTP for the peace process. These can prove to be the stumbling block. The terrorist groups or some third party wants to sabotage the negotiations. We cannot rule out India's involvement in these activities. A political drama is being staged and enacted in broad day light. Media must act responsibly and avoid spreading unconfirmed information.

No one has claimed responsibility for the attacks and I suspect no one would claim it either! KPK government needs to beef up the security so that such incidents do not occur.

TTP has disclaimed the Peshawar bomb blast and If that is true then we need to see who is responsible for the incident? All terrorist groups remain in contact with each other, and have inside information. It is incumbent on 
the State to protect its citizens, and respond to such nefarious activities. A number of religious scholars have been brutally killed in suicide attacks. Qadir Baloch warned that the government would have to retaliate if these attacks continue. He further said, that, he does not want to indulge in blame game and would like to see the peace talks precede in a cordial atmosphere.

JAVAID BASHIR, Lahore, February 4

\section{The News Letter 1:}

\section{Saving our souls}

Thursday, February 13, 2014 from Print Edition

Regardless of what happens to the ongoing negotiations, the problem we are facing is not going to go away. This is the battle for the soul of Pakistan. On one side are the weapons-wielding obscurantists, while on the other are those who wish to see Pakistan develop as a tolerant state based on equality, democracy and human freedom. A huge chunk of the population, disgusted with the corrupt administrative system and abject poverty, seem to fantasize about an Islamic state.

Women, the silent sufferers, have no say, as they are either too suppressed by traditions or awed by the thought of rebelling against their only security of home in a cruel society and state. This struggle will not end till the soul of Pakistan is won over by either side. Deferring the inevitable will not solve the problem. We will neither progress nor live in peace without deciding this issue once and forever.

Lt-Col (r) Saeed Rawalpindi

\section{The News Letter 2:}

\section{The players}

\section{Friday, February 14, 2014 from Print Edition}

If, as per reports, the Taliban claim they have not carried out violent activities in the past few days then who is responsible for them? It also raises serious questions over the dialogue process. If terrorist activities will not end by holding dialogue with the TTP, then why have the talks?

What has been the government's role in identifying the real groups behind the attacks? Does it mean that in the future, even if dialogues are successful, terrorist activities will continue? The government needs to put this question to the Taliban and itself and needs to avoid the policy of appeasing the TTP. In any case, an end to terrorist activities is the successful outcome of dialogues with the TTP. Anything less than this is failure and should not be accepted by the government.

\section{Kamran Syed Buner}

\section{The News Letter 3:}

\section{The confusion brigade}

\section{Friday, February 14, 2014 from Print Edition}

There are many confusion-mongering people in the media, the intelligentsia and the political and religious parties who have been instrumental in confusing and complicating the issue of terrorism. Their false narratives, flawed logic and unrealistic suggestions have virtually put the nation in a blind alley. The Pakistan Army has successfully concluded military operations against miscreants in Swat, South Waziristan and Bajaur. But the confusion brigade is portraying the dialogue process as the only remedy that will get the country out of this mess.

Instead of uniting the nation to fight this war, the confusion bridge is busy demoralising people by exaggerating the 'might' of the miscreants and the 'consequences' of the failure of this dialogue process. As a result, we are debating and discussing issues such as whether this is Americans' war or ours. Who is a real martyr in this war? Whether we need the supremacy of the constitution or the TTP-defined Shariah. Now, the TTP spokesman ShahidullahShahid has recommended the name of Mullah Fazlullah to lead Pakistan. Instead, I suggest a person like the schoolboy Aitzaz Hasan should lead this country, someone who not only has the vision to perceive the nature of the threat within seconds but also has the required courage to counter it.

MohsinRaza Malik Lahore 


\section{Copyrights}

Copyright for this article is retained by the author(s), with first publication rights granted to the journal.

This is an open-access article distributed under the terms and conditions of the Creative Commons Attribution license (http://creativecommons.org/licenses/by/3.0/). 